\title{
FAKTOR-FAKTOR YANG MEMPENGARUHI PENERAPAN KONSERVATISME AKUNTANSI PADA PERUSAHAAN ASURANSI YANG TERDAFTAR DI BURSA EFEK INDONESIA, BURSA MALAYSIA DAN SINGAPORE STOCK EXCHANGE TAHUN 2010-2014
}

\author{
Melisa Mamesah, David Paul Elia Saerang, Linda Lambey \\ (email: melisamamesah@gmail.com)
}

\begin{abstract}
Conservatism is the precautionary principle in uncertainty. There are many cases of accounting frauds occurred due to lack of conservatism implementation resulting financial statements are overstated. This study aims to analyze the affect of firm size, leverage, institutional ownership and audit committee to the implementation of conservatism in the insurance companies listed on Bursa Efek Indonesia, Bursa Malaysia and Singapore Stock Exchange. In this study, conservatism measured by market to book ratio. Used as sample of 11 companies. The analytical method used in this research is multiple regression. The results of this study are firm size and audit committee positively affect the implementation of conservatism. On the other hand, leverage and institutional ownership negatively affect the implementation of conservatism.
\end{abstract}

Keywords: conservatism, firm size, leverage, institutional ownership, audit committee

\section{PENDAHULUAN}

Terbukanya ASEAN Free Trade Area (AFTA) dalam rangka Masyarakat Ekonomi ASEAN (MEA) pada tahun 2016 dengan lima elemen kunci diantaranya aliran bebas barang, aliran bebas jasa, aliran bebas investasi, aliran bebas tenaga kerja terampil dan aliran bebas perpindahan barang modal membuat perusahaan-perusahaan yang terdaftar di Bursa Efek Indonesia, Bursa Malaysia dan Singapore Stock Exchange yang di dalamnya terdapat sub sektor asuransi harus memanfaatkan dengan sebaik-baiknya kesempatan yang ada dengan memaksimalkan nilai perusahaan untuk menarik minat para investor salah satunya dengan menyajikan informasi keuangan yang berkualitas sesuai dengan standar akuntansi keuangan yang berlaku yaitu dapat dipahami, relevan, dapat diandalkan dan dapat dibandingkan.

Terdapat berbagai kasus kecurangan yang dilakukan oleh perusahaan-perusahaan baik didalam negeri maupun luar negeri yang kurang menerapkan akuntansi konservatif. Kasus yang terjadi di Indonesia yaitu terungkapnya kasus mark-up laporan keuangan PT Kimia Farma yang overstated, yaitu adanya penggelembungan laba bersih tahunan senilai $\mathrm{Rp} 32.700 .000 .000$ yang merupakan 2,3 persen dari penjualan dan 24,7 persen dari laba bersih PT Kimia Farma (Harian Pelita, 2003).

Selain itu, PT Indofarma tersangkut kasus skandal overstated dalam penyajian laporan keuangan. Dari hasil penelitian, BAPEPAM (Badan Pengawas Pasar Modal) menemukan bukti-bukti di antaranya, barang dalam proses dinilai lebih tinggi dari nilai yang seharusnya dalam penyajian nilai persediaan barang dalam proses sebesar Rp 28.870.000.000. Akibatnya harga pokok penjualan mengalami understated dan laba bersih mengalami overstated dengan nilai yang sama (Qamariyah, 2004).

PT KAI tahun 2005, perusahaan BUMN itu dicatat meraih keuntungan sebesar Rp 6.900.000.000. Padahal apabila diteliti dan dikaji lebih rinci, perusahaan seharusnya menderita kerugian sebesar Rp. 63.000.000.000 (Maullana, 2015). Selain itu PT Great River International berdasarkan hasil pemeriksaan BAPEPAM menemukan kelebihan pencatatan atau overstatement penyajian akun penjualan dan piutang. Kelebihan itu berupa penambahan aktiva tetap dan penggunaan dana hasil emisi obligasi yang tanpa pembuktian (Asifa, 2015). Selain itu, masih banyak kasus-kasus lainnya seperti dijatuhkannya sanksi kepada PT Bakrie and Brothers Tbk., PT Bakrie Sumatra Plantation Tbk., PT Energi Mega Persada Tbk. dan PT Benakat Petroleum Energy Tbk., karena terbukti memoles laporan keuangannya melalui penyajian laba supaya tampak menguntungkan dan berharap publik tertarik membeli saham mereka untuk meningkatkan harga saham (Purnomo, 2010).

Kasus di Malaysia yaitu pada tahun 2004, United U-Li Corporation Berhad menyatakan informasi palsu dimana dalam laporan tahunan dan laporan keuangan untuk tahun yang berakhir 31 Desember 2004, perusahaan menyatakan bahwa laba sebelum pajak perusahaan dalam laporan itu meningkat (Securities Commision Malaysia, 2009). Kasus lainnya yaitu Megan Media Berhad yang menyajikan pernyataan palsu berkaitan dengan angka pendapatan sebesar RM 306.150.000 di laporan hasil konsolidasi kuartalan untuk periode keuangan yang berakhir 31 Januari 2007 (Securities Commision Malaysia, 2007). 
Pada bulan Juli 2007, Transmile Group Berhad diketahui membuat pernyataan menyesatkan dalam laporan kuartalannya. Pada tahun 2006, perusahaan mengalami kerugian sebesar RM 126.300.000 namun dalam laporannya perusahaan mengakui keuntungan sebesar RM 157.500.000 dan pada tahun 2005, perusahaan mengalami kerugian sebesar RM 369.600.000 namun dalam laporannya perusahaan mengakui keuntungan sebesar RM 84.400.000 (The Sun Daily, 2014).

Kasus perusahaan di Singapura yaitu S Chips (Perusahaan-perusahaan Cina yang terdaftar di Singapore Stock Exchange) diantaranya China Hongxing, produsen serat polyester Hongwei Technologies dan China Gaoxian Fibrefab Holdings Ltd telah ditangguhkan dari perdagangan karena penyimpangan akuntansi (Nexia Pulse, 2011). Kasus lainnya yaitu Noble Group. Berdasarkan penelitian Iceberg, diketahui bahwa terdapat kesenjangan sebesar $\$ 603.000 .000$ di antara carrying value dan market value yang tercatat atas nilai bunga dari anak perusahaannya yang dicatat dalam laporan tahunannya pada tahun 2013 dan 2014 (Singapore Business Review, 2015). Lo (2005) mendefinisikan konservatisme sebagai suatu pandangan pesimistik dalam akuntansi. Konservatisme dilatarbelakangi oleh pencatatan laporan keuangan perusahaan berbasis akrual. Pencatatan berbasis akrual mengandung berbagai kemungkinan yang menyebabkan pendapatan dicatat meskipun sebenarnya kas belum diterima dan beban dicatat meskipun kas belum dikeluarkan. Ketidakpastian di masa datang ini membuat suatu kondisi yang menyebabkan munculnya konservatisme akuntansi yang secara sederhana dapat diartikan sebagai tindakan kehati-hatian atau sikap pesimis dalam pencatatan laporan keuangan. Kehati-hatian ini menyebabkan angka dalam laporan keuagan dicatat lebih rendah atau lebih tinggi daripada nilai yang sebenarnya.

Sampai saat ini masih terjadi pertentangan mengenai manfaat konservatisme dalam laporan keuangan. Sebagian peneliti berpendapat bahwa laba yang dihasilkan dari metode yang konservatif kurang berkualitas, tidak relevan, dan tidak bermanfaat, sedangkan sebagian lainnya berpendapat sebaliknya. Peneliti yang memiliki pandangan kedua menganggap bahwa laba konservatif, yang disusun menggunakan prinsip akuntansi yang konservatif mencerminkan laba minimal yang dapat diperoleh oleh perusahaan sehingga laba yang disusun dengan metode yang konservatif tidak merupakan laba yang "dibesar-besarkan" nilainya, sehingga dapat dianggap sebagai laba yang berkualitas (Dewi, 2003; Sari, 2004).

Perusahaan yang memiliki total aset yang besar cenderung berhati-hati dalam menyajikan laporan keuangannya. Hal ini disebabkan oleh risiko perusahaan yang juga semakin tinggi (Agustina, Rice \& Stephen, 2015). Risiko tersebut terkait dengan biaya politis yang mungkin harus dikeluarkan perusahaan. Perusahaan akan berhati-hati dalam menyajikan angka dalam laporan keuangannya untuk menghindari biaya politis seperti pajak. Semakin rendah angka debt to equity ratio maka akan semakin baik, karena akan semakin tinggi kemampuan perusahaan untuk membayar seluruh kewajibannya (Suprihastini, 2007). Debt/equity hypothesis dalam teori akuntansi positif menyatakan perusahaan dengan tingkat hutang yang tinggi akan meningkatkan laba perusahaan agar laporan keuangan terlihat baik dimata stakeholders (Watts \& Zimmerman, 1990:139-140), namun dengan keadaan tersebut kreditor dan mekanisme good corporate governance akan mengawasi tindakan manajer agar berhati-hati dalam menyajikan angka-angka dalam laporan keuangan.

Dengan adanya kepemilikan saham oleh institusional yang tinggi ini maka pemegang saham dapat menggantikan atau memperkuat fungsi monitoring dari dewan dalam perusahaan (Ahmed \& Duellman, 2007). Kepemilikan institusional akan mempengaruhi penggunaan prinsip akuntansi yang konservatif untuk mencegah manajer melakukan tindakan oportunistiknya. Komite audit merupakan pihak akhir yang memonitor proses pelaporan keuangan perusahaan dan mereka akan mempengaruhi kebijakan yang diambil perusahaan berkaitan dengan prinsip yang digunakan dalam pelaporan keuangan (Wardhani, 2008). Komite audit akan mendorong manajer untuk menggunakan prinsip akuntansi yang konservatif untuk mencegah manajer melakukan tindakan oportunistiknya. Berdasarkan latar belakang yang telah diuraikan, maka tujuan penelitian ini adalah untuk menganalisis pengaruh ukuran perusahaan, leverage, kepemilikan institusional dan komite audit terhadap konservatisme akuntansi.

\section{TINJAUAN PUSTAKA}

\section{Penelitian Terdahulu}

Almilia (2003) meneliti Pengujian Size Hypothesis dan Debt/Equity Hypothesis yang Mempengaruhi Tingkat Konservatisma Laporan Keuangan Perusahaan Dengan Tehnik Analisis Multinominal Logit membuktikan semakin kecil size perusahaan maka semakin besar probabilitas perusahaan akan menyajikan laporan keuangan yang cenderung konservatif. Penelitian ini juga memberikan bukti bahwa semakin tinggi debt to total assets ratio maka semakin besar probabilitas perusahaan akan menyajikan laporan keuangan yang cenderung tidak konservatif atau optimis. 
Lo (2005) meneliti tentang Pengaruh Tingkat Kesulitan Keuangan Perusahaan terhadap Konservatisme Akuntansi yang berhasil membuktikan perusahaan yang memiliki biaya politis yang tinggi akan semakin konservatif dalam laporan keuangannya dan perusahaan yang memiliki rasio leverage tinggi akan cenderung meningkatkan pendapatannya sehingga pihak kreditor akan meningkatkan pengawasan atas tindakan manajer dengan meminta manajer untuk menerapkan konservatisme akuntansi.

Ahmed dan Duellman (2007) meneliti tentang Accounting Conservatism and Board of Director Characteristics: An Empirical Analysis membuktikan persentase direksi internal perusahaan berhubungan negatif dengan konservatisme, persentase kepemilikan direksi eksternal berhubungan positif dengan konservatisme. Variabel kontrol industri, ukuran perusahaan, leverage, kesempatan tumbuh, kepemilikan institusional, kepemilikan direksi internal dan karakteristik perusahaan cenderung stabil.

Krishnan dan Visvanathan (2008) meneliti tentang Definition of Accounting Expert Matter? The Association Between Audit Committee Directors' Accounting Expertise and Accounting Conservatism membuktikan latar belakang keahlian komite audit dari perusahaan yang memiliki tata kelola perusahaan yang baik, memberikan kontribusi terhadap tingkat monitoring yang lebih besar.

Wardhani (2008) yang meneliti tentang Tingkat Konservatisme Akuntansi di Indonesia dan Hubungannya dengan Karakteristik Dewan Sebagai Salah Satu Mekanisme Corporate Governance membuktikan komite audit dan komisaris independen berpengaruh positif terhadap konservatisme dan kepemilikan manajerial berpengaruh negatif terhadap konservatisme.

Fanani (2009) meneliti tentang Kualitas Pelaporan Keuangan: Berbagai Faktor Penentu dan Konsekuensi Ekonomis membuktikan terdapat perbedaan diantara atribut-atribut kualitas pelaporan keuangan dan tidak terjadi tumpang tindih (overlap) antar ketiga atribut kualitas pelaporan keuangan. Hasil pengujian faktor-faktor penentu kualitas laba menunjukkan bahwa faktor-faktor volatilitas penjualan, kinerja perusahaan, dan klasifikasi industri berhubungan positif terhadap kualitas pelaporan keuangan. Sebaliknya, siklus operasi, ukuran perusahaan, umur perusahaan, likuiditas dan leverage tidak menunjukkan pengaruh yang signifikan.

Sari dan Adhariani (2009) meneliti tentang Konservatisme Perusahaan di Indonesia dan Faktor-Faktor yang Mempengaruhinya membuktikan rasio konsentrasi, intensitas modal dan ukuran perusahaan merupakan faktor-faktor yang berpengaruh positif terhadap konservatisme.

Xia dan Zhu (2009) meneliti tentang Corporate Governance and Accounting Conservatism in China membuktikan semakin tinggi leverage semakin konservatif pelaporan keuangan perusahaan.

Hamdan, Abzakh dan Al-Ataibi (2011) yang meneliti tentang Factors Influencing the Level of Accounting Conservatism in the Financial Statements membuktikan standar akuntansi sektor publik berhasil mendorong perusahaan untuk menerapkan akuntansi konservatif, perusahaan kecil lebih konservatif dibandingkan perusahaan besar dan perusahaan dengan tingkat utang yang rendah lebih konservatif dibandingkan perusahaan dengan tingkat utang yang tinggi.

Putra (2011) yang meneliti tentang Tingkat Konservatisme Akuntansi: Kajian Berdasarkan Karakteristik Dewan Komisaris, Kepemilikan Modal Manajerial dan Keberadaan Komite Audit Sebagai Pendukung Mekanisme Good Corporate Governance membuktikan komisaris independen, kepemilikan saham oleh komisaris dan direksi, jumlah komite audit, jumlah dewan komisaris berpengaruh positif pada tingkat konservatisme akuntansi.

Mutmainnah dan Wardhani (2013) yang meneliti tentang Analisis Dampak Kualitas Komite Audit Terhadap Kualitas Laporan Keuangan Perusahaan dengan Kualitas Audit Sebagai Variabel Moderasi membuktikan keahlian komite audit terbukti meningkatkan kualitas laporan keuangan berdasarkan dua dari tiga pengukuran yang digunakan yaitu persistensi laba dan prediktabilitas laba. Hasil ini menunjukkan bahwa semakin banyak anggota komite audit yang memiliki keahlian di bidang akuntansi dan keuangan akan berdampak kepada kualitas laporan keuangan yang lebih baik.

Yustina (2013) yang meneliti tentang Pengaruh Konvergensi IFRS dan Mekanisme Good Corporate Governance terhadap Tingkat Konservatisme membuktikan ukuran dewan, kepemilikan institusional, ukuran perusahaan dan leverage berpengaruh signifikan terhadap tingkat konservatisme akuntansi. Sedangkan variabel konvergensi IFRS, proporsi komisaris independen dan kepemilikan manajerial tidak berpengaruh terhadap tingkat konservatisme akuntansi.

Sari (2013) meneliti tentang Pengaruh Struktur Kepemilikan Institutional, Struktur Kepemilikan Manajerial, Struktur Kepemilikan Publik, Debt covenant dan Growth Opportunities membuktikan komisaris independen, kepemilikan institusional dan leverage tidak berpengaruh secara signifikan terhadap praktik konservatisme akuntansi sedangkan ukuran perusahaan berpengaruh secara signifikan terhadap praktik konservatisme akuntansi. 
Chen, Li, Wang dan Wang (2015) meneliti tentang Institutional Investors and Conservative Financial Reporting: Evidence from China membuktikan kepemilikan institusional berhubungan dengan konservatisme perusahaan. Semakin lama jangka waktu kepemilikan saham oleh institusional, semakin mendorong kurangnya penerapan konservatisme.

Agustina (2015) meneliti tentang Faktor-Faktor yang Mempengaruhi Penerapan Konservatisme Akuntansi pada Perusahaan Manufaktur yang Terdaftar di Bursa Efek Indonesia membuktikan ukuran perusahaan, risiko perusahaan, struktur kepemilikan dan growth opportunity berpengaruh positif dan signifikan terhadap penerapan konservatisme akuntansi. Intensitas modal berpengaruh negatif dan signifikan terhadap penerapan konservatisme akuntansi, sedangkan leverage, pajak dan litigasi secara negatif tidak berpengaruh signifikan terhadap penerapan prinsip konservatisme akuntansi.

Sumiari dan Wirama (2016) meneliti Pengaruh Ukuran Perusahaan Terhadap Konservatisme Akuntansi dengan Leverage sebagai Variabel Pemoderasi membuktikan ukuran perusahaan tidak berpengaruh terhadap konservatisme. Sedangkan leverage merupakan variabel yang dapat memperlemah pengaruh antara ukuran perusahaan dengan konservatisme akuntansi.

\section{Teori Keagenan}

Teori keagenan (agency theory) menjelaskan bahwa hubungan agensi muncul saat satu orang atau lebih (principal) mempekerjakan orang lain (agent) untuk memberikan suatu jasa dan kemudian mendelegasikan wewenang pengambilan keputusan kepada agent tersebut (Jensen \& Meckling, 1976). Terdapat kemungkinan bahwa manajer akan memaksimalkan kepentingannya sendiri dimana kepentingan tersebut bertentangan dengan keinginan principal. Perspektif hubungan keagenan merupakan dasar yang digunakan untuk memahami corporate governance. Keberadaan struktur good corporate governance dalam perusahaan dalam hal ini kepemilikan institusional dan komite audit diharapkan dapat melakukan monitoring, sehingga kepentingan antara agent dengan principal dapat disetarakan, dalam hal ini dapat mendorong manajer untuk menerapkan konservatisme akuntansi dalam menyajikan laporan keuangan perusahaan.

\section{Teori Akuntansi Positif}

Teori akuntansi positif didasarkan pada premis bahwa individu selalu bertindak atas motivasi pribadi dan berusaha memaksimumkan kepentingan pribadi (Ghozali dan Chariri, 2014:69). Watts dan Zimmerman (1990) menyatakan ada 3 hipotesis dalam teori akuntansi positif yaitu: (1) Hipotesis Rencana Bonus (Bonus Plan Hypothesis) menyatakan bahwa manajer perusahaan dengan rencana bonus tertentu cenderung lebih menyukai metode yang meningkatkan laba periode berjalan; (2) hipotesis Hutang/Ekuitas (Debt/Equity Hypothesis) menyatakan bahwa semakin tinggi rasio utang/ekuitas perusahaan, makin besar kemungkinan manajer untuk memilih metode akuntansi yang dapat menaikkan laba. Makin tinggi rasio hutang/ekuitas, makin dekat perusahaan dengan batas perjanjian/peraturan kredit (Kalay, 1982); (3) hipotesis Biaya Politik (Political Cost Hypothesis) menyatakan bahwa perusahaan besar cenderung menggunakan metode akuntansi yang dapat mengurangi laba periodik dibandingkan perusahaan kecil.

Berdasarkan political cost hypothesis, manajer ingin mengecilkan laba untuk mengurangi biaya politis yang potensial. Ukuran perusahaan yang besar mendorong perusahaan untuk menerapkan konservatisme akuntansi dengan menyajikan angka laba yang lebih rendah disebabkan oleh biaya politik yang mungkin akan timbul di masa depan atas tuntutan pemerintah. Sedangkan menurut debt/equity hypothesis, perusahaan yang memiliki tingkat leverage yang tinggi akan cenderung menyajikan labanya lebih tinggi pada tahun berjalan untuk menghindari keraguan kreditor dalam pelunasan kewajiban perusahaan, namun kreditor akan ikut melibatkan diri dalam mengawasi tindakan manajer dengan mendorong penerapan konservatisme.

\section{Konservatisme Akuntansi}

Secara tradisional, konservatisme dalam akuntansi dapat diterjemahkan melalui pernyataan tidak mengantisipasi keuntungan, tetapi megantisipasi semua kerugian (J. H. Bliss, 1924, dikutip oleh Watts, 2003; Holthausen \& Watts, 2001). Basu (1997) dan Lara et al. (2005) mendefinisikan konservatisme sebagai pengakuan laba yang mencerminkan berita buruk dibandingkan berita baik dalam laporan keuangan.

Juanda (2007) mendefinisikan konservatisme sebagai prinsip akuntansi yang jika diterapkan akan menghasilkan angka-angka laba dan aset cenderung rendah, serta angka-angka biaya dan utang cenderung tinggi. Kecenderungan seperti itu terjadi karena konservatisme menganut prinsip memperlambat pengakuan pendapatan serta mempercepat pengakuan biaya. Akibatnya, laba yang dilaporkan cenderung terlalu rendah (understatement). 
Berdasarkan pengertian-pengertian tersebut dapat disimpulkan bahwa konservatisme akuntansi adalah prinsip kehati-hatian dalam menyajikan angka-angka dalam laporan keuangan dengan tidak mengantisipasi keuntungan sebagai berita baik melainkan mengantisipasi semua kerugian sebagai berita buruk sehingga angkaangka laba dan aset cenderung rendah, serta angka-angka biaya dan utang cenderung tinggi.

Terdapat pro dan kontra dalam penerapan konservatisme dalam laporan keuangan. Penelitian yang membuktikan bahwa akuntansi konservatif tidak berguna bagi pengguna laporan keuangan seperti investor antara lain dilakukan oleh Penman dan Zhang (1999). Kecenderungan seperti itu terjadi karena konservatisme menganut prinsip memperlambat pengakuan pendapatan serta mempercepat pengakuan biaya. Akibatnya, laba yang dilaporkan cenderung terlalu rendah (understatement) (Hati, 2011). Penelitian yang membuktikan bahwa konservatisme bermanfaat antara lain dilakukan oleh Feltham dan Ohlson (1995) dan Ahmed, Billings, Harris dan Morton (2000). Feltham dan Ohlson (1995) membuktikan bahwa penggunaan akuntansi konservatif dapat digunakan untuk menilai relevansi aktivitas operasi perusahaan. Ahmed et al. (2000) membuktikan bahwa konservatisme memainkan peran penting dalam kontrak efisien. Konservatisme akuntansi juga dianggap mengurangi asimetri informasi dengan membatasi tindakan manajer dalam memanipulasi laporan keuangan (LaFond \& Watts, 2007).

André, Filip dan Paugam (2013), Lu dan Trabelsi (2013) dan Rosdini (2014) berhasil membuktikan bahwa penerapan IFRS mengurangi konservatisme akuntansi dalam perusahaan. Berbeda dengan Yustina (2013) yang tidak berhasil membuktikan bahwa penerapan IFRS dapat mengurangi konservatisme akuntansi. Konservatisme bukan bagian dari kerangka teori tapi masih menjadi bagian dalam praktik akuntansi (W. Paton dan A. C. Littleton, 1940, dikutip oleh Hellman, 2007; Juanda, 2012).

\section{Faktor-Faktor yang Mempengaruhi Penerapan Konservatisme Akuntansi Ukuran Perusahaan}

Aset merupakan tolok ukur besaran atau skala suatu perusahaan. Biasanya perusahaan besar mempunyai aktiva yang besar pula nilainya (Sofyaningsih \& Hardiningsih, 2011). Perusahaan yang semakin besar otomatis pemerintah akan mengalokasikan biaya politis yang besar juga terhadap perusahaan tersebut. Biaya politis bisa disebabkan oleh penetapan pajak oleh pemerintah, dengan jumlah aset yang besar pemerintah akan menetapkan tarif pajak yang semakin besar juga kepada perusahaan tersebut. Semakin besar penetapan biaya pajak pada suatu perusahaan tersebut berarti penambahan pemasukan untuk pemerintah, dan perusahaan dengan total aset yang besar diasumsikan dapat membayar pajak lebih. Karena itulah semakin besar ukuran perusahaan semakin besar juga penetapan pajak untuk perusahaan tersebut (Daljono, 2013). Political costs hypothesis mengenalkan dimensi politis ke dalam konservatisme akuntansi. Ukuran perusahaan juga dapat menimbulkan biaya politis. Perusahaan yang sangat besar didirikan dengan standar kinerja dan profitabilitas yang tinggi akan meningkatkan juga biaya politis. Hal ini mendorong perusahaan-perusahaan berskala besar untuk menerapkan konservatisma akuntansi (Lasdi, 2009).

\section{Leverage}

Rasio solvabilitas terdiri dari rasio utang (debt ratio) yaitu rasio total utang terhadap total aset dan rasio solvabilitas yang lain adalah dalam bentuk Debt to Equity Ratio (DER), yaitu suatu perbandingan antara nilai seluruh hutang (total debt) dengan total modal. Keseimbangan proporsi antara aset yang didanai oleh kreditor dan yang didanai oleh pemilik perusahaan diukur dengan debt-to-equity (Prastowo, 2015:79). Pada perusahaan yang mempunyai utang relatif tinggi, kreditur mempunyai hak lebih besar untuk mengetahui dan mengawasi penyelenggaraan operasi dan akuntansi perusahaan. Hak lebih besar yang dimiliki kreditur akan mengurangi asimetri informasi di antara kreditur dengan manajer perusahaan. Manajer mengalami kesulitan untuk menyembunyikan informasi dari kreditur. Kreditur berkepentingan terhadap distribusi aktiva bersih dan laba yang lebih rendah kepada manajer dan pemegang saham sehingga kreditur cenderung meminta manajer untuk menyelenggarakan akuntansi konservatif (Lo, 2005).

\section{Kepemilikan Institusional}

Kepemilikan institusional merupakan salah satu elemen dari mekanisme eksternal Good Corporate Governance dalam mengendalikan perilaku manajemen. Kepemilikan institusional memiliki peranan yang sangat penting dalam meminimalisasi konflik keagenan yang terjadi antar manajer dan pemegang saham (Cornett, Marcus, Saunders, Hassan \& Tehranian, 2006). Dengan adanya kepemilikan institusional yang tinggi maka pemegang saham institusional ini dapat menggantikan atau memperkuat fungsi monitoring dari dewan dalam perusahaan (Ahmed \& Duellman, 2007). 


\section{Komite Audit}

Komite audit adalah komite dewan yang didasari dengan tujuan berkontribusi terhadap tata kelola perusahaan yang efektif, khususnya yang berkaitan dengan tanggung jawab dewan untuk keandalan pengungkapan keuangan dan pengawasannya terhadap efektivitas manajemen risiko, pengendalian internal dan audit (Haron, Jantan \& Pheng, 2005).

Dechow, Sloan dan Sweeney (1996) dan Beasley, Carcello dan Hermanson (2000) menyatakan bahwa adanya komite audit berhubungan dengan tingkat kecurangan yang lebih rendah. Menurut Dechow et al. (1996), perusahaan yang terkena skandal kasus kecurangan laporan keuangan kemungkinan besar tidak mempunyai komite audit atau komite auditnya tidak bekerja secara efektif dan efisien dalam setiap rapat yang dilaksanakan. Selain itu, Putra (2011) dan Krishnan dan Visvanathan (2008) membuktikan bahwa keberadaan komite audit berpengaruh positif terhadap tingkat konservatisme laporan keuangan dan latar belakang keahlian dari komite audit dari perusahaan yang memiliki tata kelola perusahaan yang baik, memberikan kontribusi terhadap tingkat monitoring yang lebih besar oleh anggota komite audit. Dengan adanya komite audit dalam suatu perusahaan, akan mendorong penerapan konservatisme.

\section{KERANGKA KONSEPTUAL}

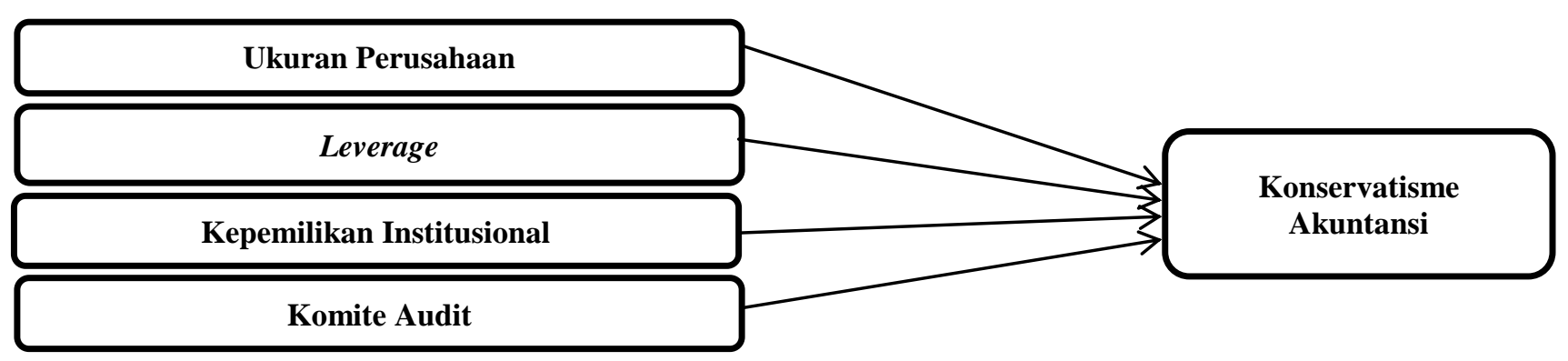

\section{Perumusan Hipotesis}

$\mathrm{H}_{1}$ : Ukuran perusahaan berpengaruh positif terhadap konservatisme akuntansi

$\mathrm{H}_{2}$ : Leverage berpengaruh positif terhadap konservatisme akuntansi

$\mathrm{H}_{3}$ : Kepemilikan institusional berpengaruh positif terhadap konservatisme akuntansi

$\mathrm{H}_{4}$ : Komite audit berpengaruh positif terhadap konservatisme akuntansi

\section{METODE PENELITIAN}

\section{Klasifikasi Variabel dan Definisi Operasional Variabel Variabel Dependen \\ Konservatisme}

H. I. Wolk, M. G. Tearney dan J. L. Dodd (2001) dikutip oleh Lo (2005) mendefinisikan konservatisme akuntansi sebagai usaha untuk memilih metoda akuntansi berterima umum yang (a) memperlambat pengakuan pendapatan (b) mempercepat pengakuan beban, (c) merendahkan penilaian aktiva, dan (d) meninggikan penilaian utang. Konservatisme diproksikan dengan market to book ratio (Beaver dan Ryan, 2000). Persamaannya dapat dituliskan sebagai berikut.

\section{Market to Book =}

Nilai Buku per Saham =

\section{Variabel Independen \\ Ukuran Perusahaan}

Ukuran perusahaan dapat diukur dengan melihat total aset yang dimiliki oleh suatu perusahaan (Alfian \& Sabeni, 2013). Ukuran perusahaan diukur dengan logaritma natural total aset perusahaan (Sari dan Adhariani, 2009). Untuk perusahaan asuransi Bursa Malaysia dan Singapore Stock Exchange total aset perusahaan dikalikan dengan kurs tengah akhir tahun Bank Indonesia terlebih dahulu kemudian dilogaritmanaturalkan untuk menyamakan nilai ukuran perusahaan asuransi yang terdaftar di Bursa Efek Indonesia. 


\section{Leverage}

Rasio leverage yaitu suatu perbandingan antara nilai seluruh hutang (total debt) dengan total modal (Prastowo, 2015:79). Leverage diukur dengan menggunakan rasio perbandingan antara total kewajiban terhadap total ekuitas (Agustina et al., 2015).

\section{Kepemilikan Institusional}

Kepemilikan institusional adalah saham perusahaan yang dimiliki oleh institusi atau lembaga seperti perusahaan asuransi, dana pensiun, atau perusahaan lain (Febiani, 2012). Kepemilikan institusional diukur dengan perbandingan antara jumlah kepemilikan saham oleh institusional dengan total saham (Yustina, 2013:8).

\section{Komite Audit}

Komite audit merupakan badan yang dibentuk oleh dewan direksi yang bertanggung jawab untuk menelaah kualitas dan integritas dari pencatatan akuntansi perusahaan dan sistem pelaporan keuangan, sistem pengendalian internal serta ketaatan terhadap hukum, peraturan dan regulasi (Adhikary \& Mitra, 2016). Komite audit diukur dengan presentase dari jumlah anggota komite audit yang mempunyai keahlian akuntansi dan/atau keuangan terhadap jumlah anggota komite audit keseluruhan (Krishnan dan Visvanathan, 2008).

\section{Populasi dan Sampel}

Populasi dalam penelitian ini adalah perusahaan-perusahaan asuransi yang terdaftar di Bursa Efek Indonesia tahun 2010-2014. Pertimbangan pemilihan sampel dalam penelitian ini adalah perusahaan asuransi yang memenuhi kriteria tertentu yaitu perusahaan asuransi yang terdaftar di Bursa Efek Indonesia, Bursa Malaysia dan Singapore Stock Exchange tahun 2010-2014, perusahaan asuransi yang laporan keuangannya berakhir pada 31 Desember, perusahaan asuransi yang memiliki kelengkapan data penelitian dan perusahaan asuransi yang konsisten menerbitkan laporan keuangan auditan dan laporan tahunan tahun 2010-2014. Jumlah sampel dalam penelitian ini adalah 11 perusahaan.

\section{Metode Analisis}

Pada penelitian ini, pengujian dilakukan dengan analisis regresi linier berganda yaitu studi mengenai ketergantungan satu variabel dependen (terikat) dengan satu atau lebih variabel independen (variabel penjelas/bebas), dengan tujuan untuk mengestimasi dan/atau memprediksi rata-rata populasi atau nilai rata-rata variabel dependen berdasarkan nilai variabel independen yang diketahui (Gujarati, 2004:18).

\section{HASIL PENELITIAN DAN PEMBAHASAN \\ Uji Asumsi Klasik}

Uji multikorelasi dilakukan untuk mengetahui adanya keterikatan antara variabel independen, dengan kata lain bahwa setiap variabel dependen dapat dijelaskan oleh variabel independen lainnya. Berdasarkan hasil uji multikorelasi, keseluruhan variabel pada model regresi memperoleh nilai VIF yang tidak melebihi angka 10, dengan nilai tolerance di atas 0,1 sehingga keseluruhan variabel pada model regresi tidak terdapat masalah multikorelasi. Uji heteroskedatisitas bertujuan untuk menguji apakah dalam sebuah model regresi terjadi kesamaan value dan residual dari suatu pengamatan yang lain. Dari hasil uji glejser, nilai signifikansi seluruh variabel independen > 0,05 sehingga dalam persamaan regresi tidak terjadi masalah heteroskedatisitas.

\section{Uji F}

Uji F digunakan untuk mengetahui pengaruh ukuran perusahaan, leverage, kepemilikan institusional dan komite audit secara bersama-sama terhadap konservatisme. Berdasarkan hasil uji $\mathrm{F}$, nilai $\mathrm{F}_{\text {hitung }} 6,692>\mathrm{F}_{\text {tabel }}$ 2,55 dan nilai signifikansi sebesar $0,000<0,05$, sehingga $X_{1}, X_{2}, X_{3}$ dan $X_{4}$ berpengaruh terhadap Y. Dengan demikian secara bersama-sama ukuran perusahaan, leverage, kepemilikan institusional dan komite audit berpengaruh terhadap konservatisme.

\section{Uji t}

Untuk mengetahui sejauh mana pengaruh secara parsial atau masing-masing variabel terhadap konservatisme, maka dilakukan uji t dengan tingkat kepercayaan 95\% dengan tingkat signifikansi 0,05 ( $\alpha=5 \%$ ). Berdasarkan hasil olahan data regresi berganda, persamaan regresinya dapat dijabarkan sebagai berikut. $\mathrm{Y}=-6,268+0,238$ FIRM_SIZE - 0,034 LEV - 0,166 INS_OWN + 1,257 COM_AUD

Berdasarkan hasil uji t, maka hasil uji t pada penelitian ini dapat dijelaskan sebagai berikut. 
1. Tingkat signifikansi pada variabel ukuran perusahaan adalah $0,004<0,05$. Nilai $t_{\text {hitung }} 2,994>t_{\text {tabel }}$ 2,00856, sehingga dapat diartikan bahwa secara individual $\mathrm{X}_{1}$ berpengaruh positif terhadap $\mathrm{Y}$, maka berarti ukuran perusahaan berpengaruh positif terhadap konservatisme.

2. Tingkat signifikansi pada variabel leverage sebesar $0,262>0,05$. Nilai $t_{\text {hitung }}-1,134<t_{\text {tabel }} 2,00856$, sehingga dapat diartikan bahwa secara individual $\mathrm{X}_{2}$ berpengaruh negatif terhadap $\mathrm{Y}$, maka berarti leverage berpengaruh negatif terhadap konservatisme.

3. Tingkat signifikansi pada kepemilikan institusional sebesar $0,742>0,05$. Nilai $t_{\text {hitung }}-0,332<t_{\text {tabel }}$ 2,00856, sehingga berarti secara parsial $\mathrm{X}_{3}$ berpengaruh negatif terhadap $\mathrm{Y}$, maka berarti kepemilikan institusional berpengaruh negatif terhadap konservatisme.

4. Tingkat signifikansi pada komite audit sebesar 0,012 $<0,05$. Nilai $t_{\text {hitung }} 2,607>t_{\text {tabel }} 2,00856$, sehingga berarti secara parsial $\mathrm{X}_{4}$ berpengaruh positif terhadap $\mathrm{Y}$, maka berarti komite audit berpengaruh positif terhadap konservatisme.

\section{Koefisien Determinasi}

Nilai adjusted $R$ square sebesar 0,297 atau 29,7 \% menunjukkan besarnya kontribusi dari ukuran perusahaan, leverage, kepemilikan institusional dan komite audit terhadap konservatisme sebesar $29,7 \%$ sedangkan sisanya 70,3\% merupakan kontribusi faktor lain yang tidak diteliti dalam penelitian ini.

\section{Pembahasan \\ Pengaruh Ukuran Perusahaan terhadap Konservatisme Akuntansi}

Hasil penelitian ini sesuai dengan teori akuntansi positif dalam political cost hypothesis yang dikemukakan oleh Watts dan Zimmerman (1990:139-140), ukuran perusahaan berhubungan dengan biaya politik. Semakin besar ukuran perusahaan, maka semakin besar biaya politik yang akan ditanggung perusahaan tersebut. Perusahaan yang berukuran besar biasanya lebih diawasi oleh pemerintah dan masyarakat (Lo: 2005). Perusahaan yang semakin besar otomatis pemerintah akan mengalokasikan biaya politis yang besar juga terhadap perusahaan tersebut. Biaya politis bisa disebabkan oleh penetapan pajak oleh pemerintah, dengan jumlah aset yang besar pemerintah akan menetapkan tarif pajak yang semakin besar juga kepada perusahaan tersebut. Semakin besar penetapan biaya pajak pada suatu perusahaan tersebut berarti penambahan pemasukan untuk pemerintah, dan perusahaan dengan total aset yang besar diasumsikan dapat membayar pajak lebih. Karena itulah semakin besar ukuran perusahaan semakin besar juga penetapan pajak untuk perusahaan tersebut (Daljono, 2013). Hal tersebut membuat manajer pada perusahaan besar lebih menyukai untuk memilih pengurangan laba portofolio pada prosedur akuntansinya (lebih konservatif) (Sari \& Adhariani, 2009). Berbeda dengan perusahaan yang termasuk dalam kategori perusahaan kecil. Perusahaan kecil lebih memilih meningkatkan nilai laba dalam laporan keuangannya. Hal ini didasari dari jumlah pajak yang dibayarkan perusahaan kecil tidak sebesar perusahaan besar dan perusahaan kecil juga tidak terlalu menjadi sorotan pemerintah. Persaingan yang semakin ketat dan daya supply yang rendah ditambah dengan sikap konsumen yang semakin kritis dan preferensi dapat memberikan dampak terhadap perusahaan. Sehingga menyebabkan perusahaan cenderung bersikap lebih konservatif di dalam pelaporan keuangannya untuk tetap bertahan di dalam persaingan. Perusahaan tentunya menginginkan kelangsungan siklus hidup yang berjalan terus, situasi perekonomian yang semakin berkembang dapat membuat perusahaan lebih konservatif dalam penyajian laporan keuangannya (Agustina et al., 2015). Hasil penelitian ini konsisten dengan penelitian Agustina et al., (2015), Sari (2013), Yustina (2013), Sari dan Adhariani (2009), Xia dan Zhu (2009) dan Lo (2005).

\section{Pengaruh Leverage terhadap Konservatisme Akuntansi}

Hasil penelitian ini memberikan bukti bahwa perusahaan yang memiliki hutang yang tinggi akan cenderung memilih metode akuntansi yang meningkatkan laba perusahaan atau laporan keuangan yang disajikan cenderung tidak konservatif atau optimis (Almilia, 2003:20). Hasil penelitian ini juga sejalan dengan debt/equity hypothesis dalam teori akuntansi positif yang menyatakan bahwa perusahaan dengan rasio debt/equity yang tinggi cenderung akan meningkatkan pendapatannya (Watts \& Zimmerman, 1990). Besarnya leverage perusahaan akan menyebabkan perusahaan meningkatkan kualitas pelaporan keuangan dengan tujuan untuk mempertahankan kinerja yang baik di mata investor dan kreditor, sehingga kreditor akan terus menyediakan dana pinjaman bagi perusahaan serta mengundang investor untuk membeli saham perusahaan. Namun tidak semua perusahaan mampu melakukan aktivitas ini karena sangat tergantung pada kredibilitas perusahaan (Fanani, 2009). Hal tersebut juga terkait dengan perilaku oportunistik manajer dalam memaksimalkan kepentingannya seperti yang dinyatakan dalam teori keagenan (Jensen \& Meckling, 1976), dalam hal ini 
membuat kinerja manajer terlihat baik di mata pemegang saham sehingga manajer terhindar dari penggantian manajer. Hasil penelitian ini konsisten dengan penelitian Sari (2013), Fanani (2009), Sari dan Adhariani (2009) dan Almilia (2003) yang dalam penelitiannya menyatakan bahwa leverage tidak berpengaruh terhadap konservatisme akuntansi.

\section{Pengaruh Kepemilikan Institusional terhadap Konservatisme Akuntansi}

Investor institusional sebagai bagian dari mekanisme good corporate governance dapat turut melakukan pengawasan dalam kegiatan maupun pengambilan keputusan dalam perusahaan. Namun dari hasil penelitian ini menunjukkan bahwa kepemilikan institusional tidak mempengaruhi perusahaan untuk menerapkan konservatisme. Hal ini disebabkan oleh tingkat pengawasan investor institusional tergantung pada waktu kepemilikan. Chen et al., (2015) menyatakan institusi-institusi yang mempunyai kepemilikan terhadap perusahaan dalam jangka waktu yang panjang ikut terlibat dalam kebijakan pelaporan keuangan yang kurang konservatif. Perusahaan yang memiliki investor institusional dalam jangka waktu yang lama akan lebih memilih menyajikan angka-angka dalam laporan keuangan secara lebih agresif untuk meningkatkan nilai tambah perusahaan. Hasil penelitian ini konsisten dengan penelitian Chen et al., (2015) dan Sari et al., (2013) yang menyatakan kepemilikan institusional tidak berpengaruh terhadap praktik konservatisme akuntansi.

\section{Pengaruh Komite Audit terhadap Konservatisme Akuntansi}

Keberadaan komite audit yang pada umumnya berasal dari pihak eksternal, yang bertugas mengkaji perencanaan audit, membuat telahaan atas berbagai hal yang relevan dengan bidang tugas dan tanggung jawabnya baik menyangkut penerapan tata kelola perusahaan, etika bisnis, informasi laporan perseroan ketaatan terhadap undang-undang serta permasalahan yang lainnya, akan berpengaruh pada tingkat konservatisme akuntansi dan pencapaian good corporate governance (Putra, 2011). Sebagai komite yang dibentuk oleh komite dewan, komite audit pada hakekatnya dapat mengurangi masalah keagenan dengan cara mengurangi asimetri informasi di antara pihak internal dan pihak eksternal perusahaan serta pihak lainnya yang berkepentingan terhadap pembuatan keputusan keuangan perusahaan (Adhikary \& Mitra, 2016). Dengan demikian komite audit dapat berperan dalam menyetarakan kepentingan antara principal dan agent dengan mendorong penerapan konservatisme dalam laporan keuangan perusahaan. Dengan adanya komite audit dalam suatu perusahaan, maka proses pelaporan keuangan perusahaan akan termonitor dengan baik. Oleh karena itu, keberadaan komite audit ini akan mendorong penerapan konservatisme yang lebih tinggi dalam proses pelaporan keuangan perusahaan. Komite audit ini akan meningkatkan kualitas keseluruhan dari proses pelaporan keuangan perusahaan dengan penggunaan prinsip konservatisme (Wardhani, 2008). Latar belakang keahlian komite audit dari perusahaan yang memiliki tata kelola perusahaan yang baik, memberikan kontribusi terhadap tingkat monitoring yang lebih besar oleh anggota komite audit (Krishnan \& Visvanathan, 2008). Hasil penelitian ini konsisten dengan penelitian Krishnan dan Visvanathan (2008), Wardhani (2008) dan Putra (2011) yang menyatakan bahwa komite audit berpengaruh positif terhadap konservatisme akuntansi.

\section{PENUTUP \\ Kesimpulan}

Ukuran perusahaan berpengaruh positif terhadap penerapan konservatisme akuntansi. Hal ini terjadi karena perusahaan-perusahaan asuransi yang terdaftar di Bursa Efek Indonesia, Bursa Malaysia dan Singapore Stock Exchange ingin terhindar dari risiko biaya politik yang tinggi dan berusaha untuk tetap bertahan dalam persaingan pasar yang penuh dengan ketidakpastian. Leverage berpengaruh negatif terhadap penerapan konservatisme akuntansi. Hal tersebut disebabkan oleh perusahaan ingin membuat laporan keuangan terlihat baik di mata investor dan kreditor sehingga kreditor akan terus menyediakan dana pinjaman bagi perusahaan serta mengundang investor untuk membeli saham perusahaan. Hal tersebut juga terkait dengan perilaku oportunistik manajer dalam memaksimalkan kepentingannya, dalam hal ini membuat kinerja manajer terlihat baik di mata pemegang saham sehingga manajer terhindar dari penggantian manajer.

Kepemilikan institusional berpengaruh negatif terhadap penerapan konservatisme akuntansi. Hal ini mungkin disebabkan institusi-institusi yang mempunyai kepemilikan terhadap perusahaan dalam jangka waktu yang panjang ikut terlibat dalam kebijakan pelaporan keuangan yang kurang konservatif. Komite audit berpengaruh positif terhadap penerapan konservatisme akuntansi. Dengan adanya komite audit dalam suatu perusahaan, maka proses pelaporan keuangan perusahaan akan termonitor dengan baik. Oleh karena itu, keberadaan komite audit ini akan mendorong penggunaan konservatisme yang lebih tinggi dalam proses pelaporan keuangan perusahaan. 


\section{Keterbatasan dan Saran}

Penelitian ini menggunakan jumlah sampel yang relatif sedikit dan periode yang relatif singkat. Berdasarkan keterbatasan tersebut disarankan untuk menambah jumlah sampel penelitian dari perusahaan sektor keuangan lainnya seperti bank atau perusahaan sektor pertanian, pertambangan, industri dasar dan kimia, aneka industri, properti dan real estate, transportasi dan infrastruktur serta perdagangan, jasa dan investasi dan menambah periode pengamatan yang lebih panjang untuk mendapatkan hasil yang lebih menyeluruh. Kontribusi variabel penelitian terhadap penerapan konservatisme berdasarkan hasil penelitian menunjukkan bahwa masih banyak faktor-faktor lain yang mempengaruhi penerapan konservatisme yang belum diteliti dalam penelitian ini seperti struktur corporate governance yaitu komisaris independen dan tingkat kesulitan keuangan perusahaan.

\section{DAFTAR PUSTAKA}

Adhikary, Bishnu Kumar dan Ranjan Kumar Mitra. 2016. Determinants of Audit Committee Independence in the Financial Sector of Bangladesh. Applied Finance and Accounting Vol. 2, No. 2, August 2016 ISSN 23742410 E-ISSN 2374-2429 Published by Redfame Publishing.

Agustina, Rice dan Stephen. 2015. Analisa Faktor-Faktor yang Mempengaruhi Penerapan Konservatisme Akuntansi pada Perusahaan Manufaktur yang Terdaftar di Bursa Efek Indonesia. Simposium Nasional Akuntansi 18 Universitas Sumatera Utara, Medan 16-19 September 2015.

Ahmed, Anwer S., Bruce Billings, Mary S. Harris dan Richard M. Morton. 2000.

Accounting Conservatism and Cost o f Debt: An Empirical Test o f Efficient Contracting. SSRN Electronic Journal March 2000.

Ahmed, Anwer S. dan Scott Duellman. 2007. Accounting Conservatism and Board of Director Characteristics: An Empirical Analysis. Journal of Accounting and Economics.

Alfian, A., dan Arifin Sabeni. 2013. Analisis Faktor-Faktor yang Berpengaruh terhadap Pemilihan Konservatisme Akuntansi. Diponegoro Journal Of Accounting Volume 2, Nomor 3, Tahun 2013, ISSN (Online): 2337-3806 Halaman 1-10.

Almilia, Luciana Spica. 2003. Teknik Pengujian Size Hypothesis dan Debt/Equity Hypotesis yang Mempengaruhi Tingkat Konservatisme Laporan Keuangan Perusahaan dengan Teknik Analisis Multinomial Logit. Jurnal Bisnis dan Akuntansi STIE Perbanas Surabaya.

André, P., Andrei Filip dan Luc Paugam. 2013. Impact of Mandatory IFRS Adoption on Conditional Conservatism in Europe. Research Center ESSEC Working Paper 1311.

Asifa, A., L., 2015. http://astamiact.blogspot.co.id/2015/12/kasus-pt-great-river-international-tbk.html. Diakses: 3 Juli 2016.

Basu, Sudipta. 1997. The conservatism principle and the asymmetric timeliness of earnings. Journal of Accounting and Economics 24 (1997) 3-37.

Beasley, M., S., Joseph V. Cercello dan Dana R. Hermanson. 1999. Fraudulent Financial Reporting: 1987-1997 An Analysis of U.S. Public Companies. Committee of Sponsoring Organizations of the Treadway Commission.

Beaver, William H. dan Stephen G. Ryan. 2000. Biases and lags in book value and their effects on the ability of the book-to-market ratio to predict book return on equity. Journal of Accounting Research Vol. 38 No. 1 Spring 2000 Printed in USA.

Chen, Yue, Lingxiang Li, Haizhi Wang dan Peng Wang. 2015. Institutional Investors and Conservative Financial Reporting: Evidence from China. Eurasian Economic Review June 2015, Volume 5, Issue 1, pp $161-178$.

Cornett, Marcia Millon, Alan J. Marcus, Anthony Saunders dan Hassan Tehranian. 2006. Earnings Management, Corporate Governance, and True Financial Performance. SSRN Electronic Journal January 2006.

Daljono, W., P., H. 2013. Pengaruh Ukuran Perusahaan, Rasio Leverage, Intensitas Modal, dan Likuiditas Perusahaan Terhadap Konservatisme Akuntansi Perusahaan (Studi pada Perusahaan yang Belum Menggunakan IFRS). Diponegoro Journal of Accounting Volume 2 Nomor 3 Tahun 2013, Halaman 1 ISSN (Online): 2337-3806.

Dechow, Patricia M., Richard G. Sloan dan Amy P. Sweeney. 1996. Causes and Consequences of Earnings Manipulation: An Analysis of Firms Subject to Enforcement Actions by the SEC. Contemporary Accounting Research Vol.13 No.l (Spring 1996) pp. 1-36.

Dewi, A., A., A., R. 2003. Pengaruh Konservatisma Laporan Keuangan terhadap Earnings Response Coefficient. Simposium Nasional Akuntansi VI Surabaya. 
Fanani, Z. Kualitas Pelaporan Keuangan: Berbagai Faktor Penentu dan Konsekuensi Ekonomis. Jurnal Akuntansi dan Keuangan Indonesia, Juni 2009, Vol. 6, No. 1, hal 20 - 45.

Feltham, Gerald A. dan James A. Ohlson. 1995. Valuation and Clean Surplus Accounting for Operating and Financial Activities. Contemporary Accounting Research Vol. 11 No. 2 (Spring 1995) pp 689-731.

Ghozali, Imam dan Anis Chariri. 2014. Teori Akuntansi International Financial Reporting Standard (IFRS) Edisi 4. Badan Penerbit Universitas Diponegoro. Semarang.

Gujarati, Damodar N. 2004. Basic Econometrics Fourth Edition. McGrawHill Higher Education.

Hamdan, Allam Mohammed Mousa, Mohammed Hasan Abzakh dan Mahmud Hosni Al-Ataibi. 2011. Factors Influencing the Level of Accounting Conservatism in the Financial Statements. International Business Research Vol. 4, No. 3; July 2011.

Harian Pelita. 2003. Bapepam Denda Direksi Kimia Farma Rp 1 Miliar. http://www.pelita.or.id/baca.php?id=5681. Diakses: 2 September 2016.

Haron, H., Muhamad Jantan dan Eow Gaik Pheng. 2005. Audit Committee Compliance with Kuala Lumpur Stock Exchange Listing Requirements. International Journal of Auditing Int. J. Audit. 9: 187-200 (2005).

Hati, L., A., D. 2011. Telaah Literatur tentang Faktor-Faktor yang Mempengaruhi Konservatisme Akuntansi. Jurnal Ekonomi \& Pendidikan, Volume 8 Nomor 2, November 2011.

Hellman, N. 2007. Accounting Conservatism Under IFRS. Stockholm School of Economics Department of Accounting and Managerial Finance. Stockholm, Sweden.

Jensen, M., dan William Meckling, 1976. Theory of the Firm: Managerial Behavior, Agency Cost, and Ownership Structure. Journal of Financial Economics, 3, 305-360.

Juanda, A. 2012. Kandungan Prinsip Konservatisme dalam Standar Akuntansi Keuangan Berbasis IFRS (International Financial Reporting Standard). Jurnal Humanity, ISSN: 0216-8995 Volume 7, Nomor 2, Juli $2012: 24-34$.

Krishnan, Gopal V. dan Gnanakumar Visvanathan. 2008. Does the SOX Definition of an Accounting Expert Matter? The Association between Audit Committee Directors' Accounting Expertise and Accounting Conservatism. Contemporary Accounting Research Vol. 25 No. 3 (Fall 2008) pp. 827-57.

LaFond, Ryan dan Ross L. Watts. 2007. The Information Role of Conservatism. The Accounting Review: March 2008, Vol. 83, No. 2, pp. 447-478.

Lasdi, L. 2009 Pengujian Determinan Konservatisma Akuntansi. Jurnal Akuntansi Kontemporer, Vol. 1 no. 1 Januari 2009 Hal. 1-20.

Lo, E., W. 2005. Pengaruh Tingkat Kesulitan Keuangan Perusahaan terhadap Konservatisme Akuntansi. SNA VIII Solo, 15 - 16 September 2005.

Lu, C. dan Samir Trabelsi. 2013. Information Asymmetry and Accounting Conservatism Under IFRS Adoption. Social Science Research Network CAAA Annual Conference 2013.

Mutmainnah, N. dan Ratna Wardhani. 2013. Analisis Dampak Kualitas Komite Audit terhadap Kualitas Laporan Keuangan Perusahaan dengan Kualitas Audit sebagai Variabel Pemoderasi. Jurnal Akuntansi dan Keuangan Indonesia Volume 10 Nomor 2, Desember 2013.

Nexia Pulse 1 May 2011 Associated with Smith \& Wflliamson. 2011. SGX Latest Initiatives Following Recent Scandals Over S-Chips Companies. http://www.nexiats.com.sg/uploads/publication/Articles/May\%202011\%20Nexia\%20Pulse_SGXS\%20Chip.pdf.

Penman, Stephen H. dan Xiao-Jun Zhang. 1999. Accounting Conservatism, the Quality of Earnings, and Stock Returns. The Accounting Review 77(2) December 1999.

Prastowo, D. 2015. Analisis Laporan Keuangan Konsep dan Aplikasi Edisi Ketiga. Unit Penerbit dan Percetakan Sekolah Tinggi Ilmu Manajemen YKPN.

Purnomo, $\quad$ H. $2010 . \quad$ Bank Capital Bantah Ada Rush. http://finance.detik.com/read/2010/07/26/080108/1406306/5/bank-capital-bantah-ada-rush. $\quad$ Diakses: 19 Agustus 2016.

Putra, I., W. 2011. Tingkat Konservatisme Akuntansi: Kajian Berdasarkan Karakteristik Dewan Komisaris, Kepemilikan Modal Manajerial dan Keberadaan Komite Audit Sebagai Pendukung Mekanisme Good Corporate Governance. Tesis. Universitas Udayana. Denpasar.

Qamariyah, N. 2004. Bapepam Denda Mantan Direksi Indofarma Rp 500 Juta. http://finance.detik.com/read/2004/11/08/165712/238077/6/bapepam-denda-mantan-direksi-indofarma-rp500-juta. Diakses: 7 Maret 2016. 
Rosdini, D. 2014. Dampak Penerapan IFRS 6 terhadap Konservatisme pada Perusahaan Pertambangan dan Energi di Australia. SNA 17 Mataram, Lombok Universitas Mataram 24-27 Sept 2014.

Sari, C. dan Desi Adhariani. 2009. Konservatisme Perusahaan di Indonesia dan Faktor-Faktor yang Mempengaruhinya. SNA 12 Palembang Universitas Sriwijaya 3-9 Nov 2009.

Sari, Dahlia. 2004. Hubungan antara Konservatisme Akuntansi Dengan Konflik Bondholder-Shareholder seputar Kebijakan Dividen dan Peringkat Obligasi. Jurnal Akuntansi dan Keuangan Indonesia Vol. 1, No. 2, Desember 2004 pp.63-88.

Sari, V., M. 2013. Pengaruh Corporate Governance, Leverage, dan Ukuran Perusahaan terhadap Praktik Konservatisme Akuntansi. Jurnal akuntansi Universitas Lampung.

Securities Commision Malaysia. 2007. SC charges Megan Media financial controller and executive chairmanSeeking Interpol help to arrest Megan Media executive director. http://www.sc.com.my/post_archive/sccharges-megan-media-financial-controller-and-executive-chairman-seeking-interpol-help-to-arrest-meganmedia-executive-director/. Diakses: 19 Agustus 2016.

Securities Commision Malaysia. 2009. SC charges United U-Li Corporation Berhad's external auditor for inflated profit. http://www.sc.com.my/post archive/sc-charges-united-u-li-corporation-berhads-externalauditor-for-inflated-profit/. Diakses: 19 Agustus 2016.

Singapore Business Review. 2015. Noble Group's share price tumbles on alleged accounting fraud. http://sbr.com.sg/agribusiness/news/noble-group\%E2\%80\%99s-share-price-tumbles-alleged-accountingfraud. Diakses: 20 Agustus 2016.

Sofyaningsih, S. dan Pancawati Hardiningsih. 2011. Struktur Kepemilikan, Kebijakan Dividen, Kebijakan Utang dan Nilai Perusahaan. Dinamika Keuangan dan Perbankan, Mei 2011, Vol. 3, No. 1 ISSN :19794878 Hal: $68-87$.

Sumiari, Kadek Nita dan Dewa Gede Wirama. 2016. Pengaruh Ukuran Perusahaan Terhadap Konservatisme Akuntansi dengan Leverage Sebagai Variabel Pemoderasi. E-Jurnal Ekonomi dan Bisnis Universitas Udayana 5.4 (2016): 749-774.

Suprihastini, Eka dan Herlina Pusparini. 2007. Pengaruh Tingkat Kesulitan Keuangan dan Tingkat Hutang Terhadap Konservatisme Akuntansi pada Perusahaan Manufaktur yang Terdaftar di Bursa Efek Jakarta 20012005. Jurnal Riset Akuntansi Aksioma Volume 6. Nomor 1 Juni 2007.

The Sun Daily. 2014. Transmile - the fall of a national cargo carrier. http://www.thesundaily.my/news/1157215. Diakses: 19 Agustus 2016.

Wardhani, R. 2008. Tingkat Konservatisme Akuntansi di Indonesia dan Hubungannya dengan Karakteristik Dewan Sebagai Salah Satu Mekanisme Corporate Governance. Simposium Nasional Akuntansi XI Pontianak.

Watts, Ross L. 2003. Conservatism in Accounting Part I: Explanations and Implications. Accounting Horizons Vol. 17, No. 3 September 2003 pp. 207-221.

2003. Conservatism in Accounting Part II: Evidence and Research Opportunities. The Bradley Policy Research Center Financial Research and Policy Working Paper No. FR 03-25.

Watts, Ross L. dan Jerold L. Zimmerman. 1990. Positive Accounting Theory: A Ten Year Perspective. The Accounting Review Vol. 66 No. 1 January 1990 pp. 131-156.

Yustina, R. 2013. Pengaruh Konvergensi IFRS dan Mekanisme Good Corporate Governance Terhadap Tingkat Konservatisme Akuntansi. Jurnal Ilmiah Mahasiswa FEB Universitas Brawijaya Vol 1, No 2. 